\title{
PEDAGOGICAL PSYCHOLOGICAL CORRELATIONS OF POTENTIALS AND ABILITIES
}

\author{
Anna Līduma \\ Riga Teacher Training and Educational Management Academy
}

\begin{abstract}
The existing diverse opinions of pedagogues on innate potentials and abilities stimulated carrying out of the research. The research provides characteristics correlations of potentials and abilities in musical activity. The theoretical basis is found in the verities on the essence of innate potentials and abilities by such psychologists as Rubinshtein, Teplov, Bodalev, etc, music psychologists' (Mjasishchev and Gotsdiner etc.) verities on manifestations of giftedness and musicality levels. For promotion of pedagogically psychological means, the verities by psychologist Students, pedagogues Dekens and Vikmane are researched. The objective and subjective conditions for activating of potentials and abilities have been researched, the promotion practice of abilities has been analyzed at preschool pedagogical process in x primary school in the school year of 2013/2014.
\end{abstract}

Key words: innate potentials, abilities, pedagogical means, objective and subjective conditions, collaboration.

\section{Introduction}

The ongoing changes in the pedagogical process at Latvia's preschool have caused different opinions in pedagogues and parents about the child activity impact on development of the child's abilities, knowledge, skills, experiences and attitudes have fostered the research on innate potentials and abilities gained during life span. The music teacher's experience at music sessions in preschool of primary school $x$ reveals that the child's potentials, the teacher's keen insight, purposeful activity and collaboration with the child's parents are significant for choice of means for the child's abilities development by integrated school sessions and at home. Therefore, this research was required to establish the essence of potentials and abilities, their correlation in music sessions and simultaneous preschool pedagogical process in the school year of 2013/2014. Researched have been the potentials' development determining objective and subjective conditions, pedagogical means for activating of potentials and development of abilities have been established and used.

The study provides an insight into the author's pedagogue's practice for simultaneous perception abilities development in preschool music in a 5 year olds group from September - December in the school year of 2013/2014. The pedagogical means for the multiple intelligence development promotion objective and subjective conditions have been established and analyzed at preschool pedagogical process in $\mathrm{x}$ primary school. The research theoretical basis involves ideas forwarded on potentials and abilities by psychologists Rubinshtein, Bodalev, Zaporozhec, as well as the music psychologists' (Teplov, Petrushin and Starcheus) findings on children giftedness manifestations by the child's aspirations to participate in musical activities. The psychologists' 
(Mjasishzhev and Gotsdiner) findings on the child musicality development correlations by musical activities are at the basis of the teacher's purposeful activity promotion. Pedagogical psychological means were established thanks to the findings on benevolent influence of collaboration connecting children, parents and teachers in the process of the child simultaneity skills development by pedagogue Dekens (Dēķens), psychologist Students, doctor Zheigurs (Žeigurs) and the author of the article.

The aim: to establish correlations of potentials and abilities and to establish the pedagogical means for development of abilities.

Methods: analysis of theoretical sources, empirical methods: observations.

\section{The essence and characteristics of potentials and innate abilities}

Potentials and abilities have been researched multiple times by psychologists. S.Rubinshtein writes that abilities appear in the human's life as a variable, they are not given only once, not limited by potentials, they are developed in action. Any ability stimulates activity, yet for the performance of a definite activity, more or less specific personal abilities are required. As prerequisites for ability development serve innate potentials. The human potentials differ due to the innate peculiarities in the structure of brain apparatus and also anatomically due to physiological functioning peculiarities of the human. Potentials are miscellaneous and can find development in various directions. Potentials serve as preconditions for development of abilities. Abilities develop on the basis of potentials; nevertheless, those are not functions of potentials. Those are development functions, where the potentials serve as origins, prerequisites (Rubinshtein, 1989:122-123).

Rubinshtein believes that heredity serves as one of conditions for the human development, while abilities are not a direct heredity function. As an example of the heredity of abilities, he mentions the Bach's dynasty phenomenon. The Bach's dynasty phenomenon, when through several generations appeared 18 outstanding musicians. "Abilities are a complex, synthetic personality quality, which determine the validity of personality functioning: more or less specific qualities needed for performance of a certain activity, and it can find development, on the basis of respective potentials and only by activity and through an action" (Rubinshtein, 1989:126).

It should be mentioned that three types of abilities are distinguished in psychology: a) general abilities, b) specific abilities, c) practical abilities. General abilities, specific abilities and practical abilities represent an integral formation possessing common correlations. General abilities are connected with the human's performance activity by leadership conditions. General intelligence is distinguished among them, where thinking, perception, attention, memory are components of general abilities. 
A.Bodalev believes that general abilities are psychic qualities that correspond to more than one performance activity requirements and specific psychological peculiarities (Bodalev, 1988:10). In order to accomplish a certain activity, specific abilities helping to perform the respective activity, simultaneously with the general abilities should be developed. As maintained by psychologists, specific abilities can reach up onto a high level on the basis of general abilities, yet not in every profession, for example, in pedagogy, in medicine the practical abilities can reach a high level without developed general abilities or advanced intelligence (Bodalev, 1988: 29). Practical abilities develop by performing a definite work.

Researches reveal that the development of specific abilities is a complex process. General abilities and specific abilities are mutually correlated. According to Rubinshtein - "The higher the specific ability, the closer the link with general abilities" (Rubinshtein, 1989:131). The level of abilities changes in the development process due to differentiation or specialisation of abilities. For example, giftedness in arts - especially in music - can appear early. Especially outstanding giftedness is called a talent or a genius (Rubinstein, 1989:132). The psychologist V. Druzhinin and music psychologists V. Petrushin, M. Starcheuss point out that the human giftedness is disclosed by a tendency to enter the respective field of activity. L. Venger stresses that "potentials do not determine the development of certain ability or not, the ease and speed degree determines how he will develop various ability types" (Vengers, 1973:74). Prerequisites for ability development are the following: 1) innate brain traits, 2) the child's activity and 3) ability development stimulating environment.

Psychologist A. Zaporozhec writes that "potentials are inherited anatomicallyphysiological peculiarities including, e.g., auditory analyzer peculiarities, which can be different in individuals. Potentials are only one of prerequisites for ability appearance, yet it is not the driving reason that would simultaneously determine the character and level of abilities" (Zaporozhec, 1986:79). He believes that the human abilities are not genetically inherited. They are not the respective potentials, they are developed on the basis of potentials: 1) by the subject activity process, 2) due to the impact of external conditions determining and 3) due to upbringing (Zaporozhec, 1986:79). According to Zaporozhec the human's abilities in ontogenesis develop through learning and activity processes acquiring phylogenetic historical experience of mankind. Thus, abilities develop and appear in the process of development in the human activity quality.

Teplov points out that the abilities can be discovered by analysis of activity peculiarities. The successful activity of the human depends on the multiple intelligences, where the compensation of one ability by another is possible, especially in childhood $(0-7)$. The human psycho-physiological individual peculiarities are significant for ability discovering. His researches on individual peculiarities were based on I. Pavlov's ideas about the traits of the nervous system, i.e., about the two parts of the definite nervous system type (power - 
weakness, dexterity - inertness). Teplov insisted that the typological traits' disparities have to be perceived as chance of their peculiarity not as a nervous system differences in the degree of perfection (Teplov, 1985:9-11). When displaying characteristics of abilities, he pointed out that, although, the individual nervous system traits are innate, they cannot be regarded as innate, as they initiate their development in prenatal period and continue during the first years of life. The child central nervous system continues development several years after the child's birth. The researches on development are ongoing in differential psycho-physiology.

According to Eysenck in the success structure of the talent $80 \%$ depend on inborn, including verbal communication ability, memory, imagination, ability to calculate, while the remaining $20 \%$ are provided by social conditions (family, school, chance and good luck) (Eysenck, 1992).

The $20^{\text {th }}$ century personologist $\mathrm{R}$. Cattel's 16 individual traits theory is based on multiple traits shaping the individuality. The internal factor is the conditionality of traits and heredity, innate degree, while the external: impact of environment, as well as, behaviour influencing correlation interaction of genetic factor and environment (Cattel, 1979).

Cattel differentiates general or common and unique traits. He considers that traits do not possess neuro-physiological status and they can be established precisely only by measuring the behaviour of the human. Abilities as traits determine the human's skills efficiently reach the envisaged aim. Cattel regards that common/general traits at various degrees are possessed by every representative of the same culture, while unique traits appear in a few or none of the humans, and find their manifestation in individual's interests, inclinations, orientations. The personality traits are established by analysis of factors (Cattel, 1979).

Conclusion can be drawn that the $20^{\text {th }}$ century psychologists had characterized the potentials in various ways: 1) as inborn brain qualities, 2) developed in activities or 3 ) as human psyche trait regulating knowledge, skills and abilities.

\section{Correlations of potentials and abilities in musical activity}

Psychologists Miasishchev and Gotsdiner also point out that the human can possess inclination to perform a certain activity. Significantly, that by some definite activity it is manifested for the first time, but later abilities find their development - a combination of myriad of innate and obtained during the life peculiarities. Meanwhile, the development of abilities is determined by miscellaneous conditions, tasks set for activity and mastering of various activity types (Miasishchev, Gotsdiner, 1992:19).

They discuss two approaches to the comprehension of potentials. In $30 \mathrm{~s}-40 \mathrm{~s}$ in the theory forwarded by Rubinstein and Teplov the concept of potentials is regarded as peculiarities of anatomic physiological nervous system and brain. 
Yet according to Miasishchev and Gotsdiner the scientific researches in genetics, neurophysiology and other special sciences, have not proved as valid the assumption of potentials' anatomic physiological origin.

Therefore, they consider as scientifically more valid the other psychological definition of potentials, which describes the potentials as innate traits and abilities as personality traits acquired during life span, which facilitate acquisition of a type of activities and allow implementing it at high advanced quality level. Their researches on musicality show that the increased initial emotional response to music causes aptitude to musical activities; moreover, musical activities stimulate hearing - motoric ability development, and meanwhile - development of musical hearing and rhythm feeling. Thus, the prerequisites for ability developments could be some peculiar psychic traits (Miasishchev, Gotsdiner, 1992:20-21). The psychological correlations of potentials can be more clearly depicted schematically (see Figure1).

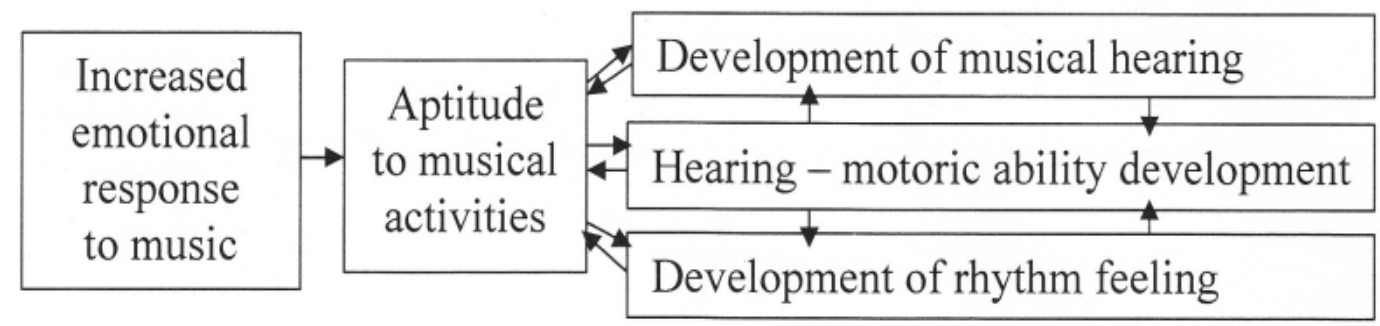

Figure 1 The psychological correlations of potentials

Gradually develops a complex functional system. The developments acquired during the life span appear as a result of its activity. Characterising the innate and the acquired in the musical abilities, Mjasishchev and Gotsdiner substantiate that "the ability to analyze specific sound signals - speech and musical - is inborn, genetically inherited, strengthened in the process of evolution of humanity, but the degree of sound distinguishing, differentiation of acuteness and skills of singing are acquired during life span" (see Figure 2.).

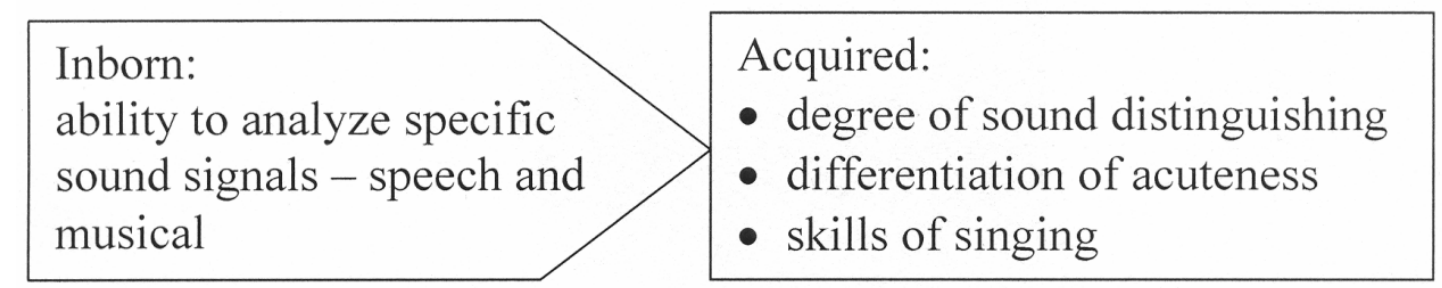

Figure 2 Inborn and acquired in musical abilities

Their acquisition level is determined by objective conditions:

1) purposefully organized teaching/learning and upbringing;

2) speech and musical experience acquisition amid a certain social environment;

3) definite music culture. 
The quality of abilities is individual. The subjective conditions for development of musical abilities are innate potentials and the child's individual activity. See Table 1.

Table 1

The objective and subjective conditions for facilitating abilities

\begin{tabular}{|l|c|}
\hline Objective conditions & Subjective conditions \\
\hline 1) purposefully organized & 1) innate potentials \\
teaching/learning and upbringing & 2) child's individual \\
2) speech and musical experience & activity \\
acquisition amid a certain social & \\
environment social environment & \\
3) definite music culture & \\
\hline
\end{tabular}

It is important to know that development of musicality facilitates tonal languages, which have a sense differentiating function following the change of sound pitch. European timbral language acquisition peculiarities and sequence is one of the reasons, which during the timbral language acquisition period oppress and hinder sound pitch hearing acquisition, therefore, musical development is belated or for a time stays in latent position. Observations of musically gifted children have revealed that the development of voice and hearing is facilitated by multiple differing sound imitations, music listening and frequent singing. Teplov, Gotsdiner and Mjasishchev point out that exactly the ability to sing is an innovation developed during the life span. No human possesses the ability to sing as innate. Even the most gifted children learn in activity to reproduce the melody by voice, to keep precise intonation, properly account for the rhythm, yet this learning process has taken place at such an early age, so fast and easy, like playing a game, that it is not noticed neither by parents nor pedagogues. Thus, a conclusion can be drawn that the following sequence appears in the musicality development process: initially higher activity responding to musical impressions causes disposition to listen to music, perform and compose it. It grows into a sustainable need to engage with music (see Figure 3 ).

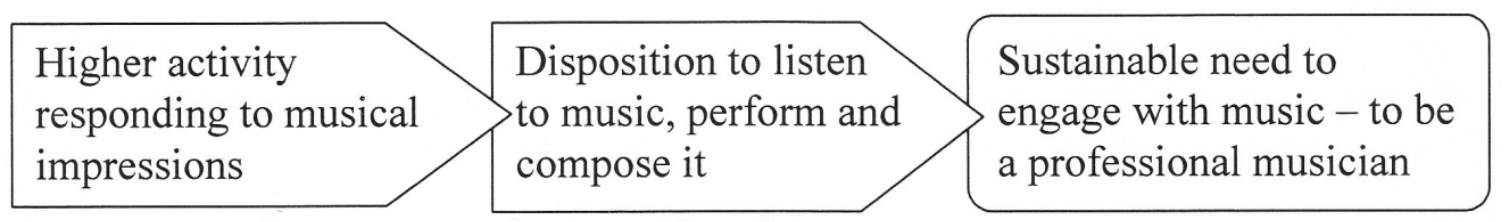

Figure 3 Correlations of musicality development process

Dialectical link between skills and activities is manifested through two main channels: 1) at some moments and in various situations by primary correlation to activity showing desire for music and demonstration of certain innate traits or their complex manifestation, 2) in another situation - activity takes lead as 
fundamental form and main cause for ability development (Miasishchev, Gotsdiner, 1992, 22-23). Correlations between abilities and activity are displayed in Figure 4.

\begin{tabular}{|l|l|}
\hline $\begin{array}{l}\text { Desire for music and innate traits } \\
\text { or their complex manifestation is } \\
\text { primary versus activity }\end{array}$ & $\begin{array}{l}\text { Activity is primary versus ability } \\
\text { development - fundamental form and } \\
\text { main cause of ability development }\end{array}$ \\
\hline
\end{tabular}

Figure 4 Correlations between abilities and activity

Musicality is manifested by activity. Thus, musical activity as a process, and musicality - as a personality potential mutually interact (see Figure 5).

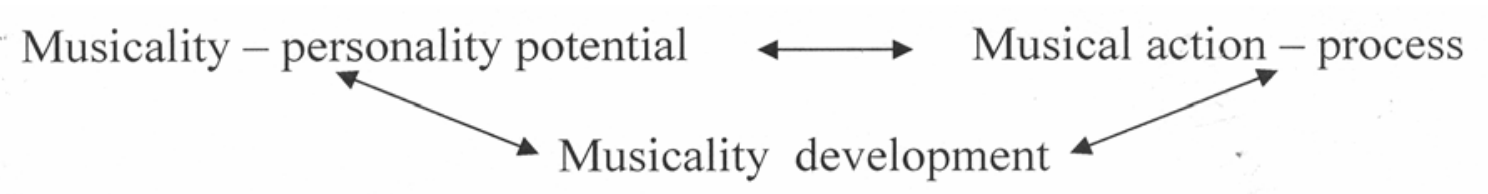

Figure 5 Musicality development

In summary, the findings on musicality by Starcheus (1996), Teplov (1985), Mjasishchev, Gotsdiner (1992) can be characterized at three levels of musicality:

1. High musicality level, which appears early as desire or ambition and there is no need for adult support in musicality acquisition.

2. Good and satisfactory musicality level, which intensively develops in the teaching/learning process. Musicality can manifest itself autonomously or taking after adults example and advice.

3. Unsatisfactory musicality level, where the child develops with difficulty and reaches not a very high level thanks to musical upbringing. Nevertheless, musicality by nature is dynamic.

Miasishchev and Gotsdiner maintain that much in its development is conditioned by the human's personality qualities and character traits, volition, being enterprising, determination (Miasishchev, Gotsdiner, 1992:23), pointing out that abilities commence musicality development.

Thus, abilities as the human peculiarities help to implement into practice the needed knowledge, skills and developed abilities. Developed abilities, possessed by any human, develop on his potentials, innate predispositions, which exist covered till the human commences a certain activity. Therefore, potentials can for a longer time remain undiscovered without a special training, never taking the shape of abilities (Petrushin, 1997:219).

Nevertheless, the human potential abilities appear in desire for activity in the respective direction, field; more speedy success in the field than others succeed in similar conditions; by higher quality of work. 
By research of the theoretical sources it was established that abilities are of two kinds: a) reproductive; b) creative. Therefore, in practice it is very important to diagnose abilities in due time. It can be done by observation. The ability detection guide is adult acumen and theoretical knowledge on correlation of potentials and abilities. It has been discovered that the preschool childhood is the sensitive period of any ability development. The child is creative since the birth, and the benevolent period for development of creativity is from 3-5 years, when the child's speech is developed and he is socializing in community. Therefore, it is important to timely facilitate development, as the latent period in creativity demonstration begins at the age of 6 , which is caused by criticism and abstract perception formation in the child's consciousness. A supportive environment is needed for facilitating of creative abilities development process, in order to take the shape of a stable personality, not appear as a situational behaviour trait (Druzhinin, 2000).

The condition for ability development is high ambition to yourself. To facilitate the development of abilities means to create conditions, which actualize both the existing and stimulate new, potential abilities. Therefore, in pedagogical activity it is essential to respect the child's desires and facilitate the child's development by stimulating assignment.

\section{Pedagogical psychological means for facilitation of abilities}

In Latvia the purposeful activity in facilitating of children ability development opportunities have been accentuated both in pedagogy and psychology in the $20^{\text {th }}$ century. K.Dekens divided the abilities into physical and intellectual, and wrote that it is important to consider the individual peculiarities, the child's innate preference. Those can be anatomic and physiologic peculiarities of the body, some peculiarities of brain structure, which are a prerequisite for the individual's development. Therefore, teaching has to be oriented so that the learning causes a definite intellectual and volitional effort to the learner (Dēķens, 1919:118-121).

J.A.Students wrote that the necessity to develop the innate gifts in all fields, especially in arts, nevertheless, he pointed out that the "artistic gifts are both meant to develop and create by upbringing and especial education, and the original foundations of the giftedness lie in the human's innate structure" and accentuated that neither the musical hearing nor the ability of drawing and the precision of drawing can be created during the process of upbringing and education, you can be only facilitate their development as the basis has already been given (Students, 1998:243).

Accentuating the significance of activity in ability development, M.Shtal pointed out that an impulse is needed for any activity driving onwards as "the presence of abilities in the child make implementation of work possible, it does not make the work accomplished" (Štāls, 1935:134). 
It is important to timely set diagnosis of abilities and develop them gradually throughout the process of play, education and training. Doctor A.Zheigurs accentuates the significance of parents' attention to timely facilitation of the child's development in early childhood; so that the child's intellectual abilities are gradually developed up to the school age. Careful adult work in the family can positively influence development of all abilities (Žeigurs, 1993).

The author of the article agrees with the conclusion by B.Vikmane (1995), a pedagogy researcher that timely developed musical abilities in the sensitive age stage facilitate the child's holistic ability development at preschool and I.Vilde's (2013) idea about facilitating of their consecutive development in the pedagogical process at early primary school.

Carrying out work at preschool, it is important for the pedagogue to know the essence of the abilities and dynamics in the personality structure, nevertheless, to use one's miscellaneous discipline and synthesis causing, creative, respectful, aesthetic and pedagogical powers so that theory assists to practice consecutively in facilitating the children ability development. It serves as a significant pedagogical means in facilitating the child's abilities.

The author's observations during the practice as a music pedagogue in interests' education of fifteen 4-5 year olds' music sessions at preschool from September to December of 2013 proved psychologists' findings that the potentials in children are very diverse. It is important for the adults timely stimulate children's diverse activity by pedagogical means. The youngest (4 year old) child in the group of 15 children did not have a prior experience of singing and displaying the musical impressions by colours. The music sessions were organized so that simultaneous activity (simultaneous singing and colouring) was done. During 3,5 months (October - middle December) changes in the fouryear old child's activity had been observed. At first the child was only playing with a toy car. The 5-year olds noticed that and asked the teacher why the boy did not join in the purposefully organized activity and did not take part in painting. It was explained that the boy would observe the other children at activity, gradually would adjust himself to the preschool pedagogical environment and in due time would be able to carry out the practised simultaneous activity: would sing and display the musical impressions by colours. In several sessions the desire to colouring appeared, the tendency to carry out work carefully developed, interesting colour arrangements were observed, the child could both concentrate his attention for a longer time and without difficulty could exchange from one type activity to another. Thus, the timely activated potentials developed into abilities in practice. The psychologist's G.Craig (2002) findings that 5 year olds develop the ability to write were proved in practice as well. 


\section{Conclusion}

The analyses of pedagogy and psychology findings reveal that abilities develop on the basis of innate potentials. Potentials are innate personality traits, among them are also peculiarities of hearing analyser, which qualitatively differs in every human, and exist as intrinsic prerequisite for appearance of the abilities. The easiness and speed level, by which the person will acquire various ability types, depends on potentials. Abilities are complex, synthetic personality qualities, which influence the human's activity. Those are more or less specific qualities, which are needed in order to carry out the activity, which develops only due to the activity. The subjective prerequisites of ability development are innate brain traits, the child's activity and the objective condition is benevolent environment facilitating ability development. The life style, personality ambition, interests, the human's personal qualities and attitude to work are factors influencing the development of abilities. The facilitating pedagogical means are timely child development diagnosis identification, purposeful work by adults and ability development nourishing content.

\section{References}

1. Cattel, R. (1979). 16 Personality Factors. Available at: http://en.wikipedia.org/wiki/ 16_Personality_Factors\#Raymond_Cattell.27s_16_Personality_Factors_.2816_PF.29

2. Dēķens, K. (1919). Rokas grāmata pedagogìīā. R.: Kultūras Balss, 238 lpp.

3. Gardner H. (2007). Five Minds for Future. Harvard Business, Boston, MA. 195 p. Available at: http://www.amazon.com/gp/reader/1591399122/ref=sib_dp_srch_pop?v= search inside\&keywords $=$ References\&go. $\mathrm{x}=12 \& \mathrm{go} . \mathrm{y}=9 \& \mathrm{go}=\mathrm{Go} \% 21 \mathrm{\#}$

4. Līduma, A. (2013). Bērnu lìdzsvarotas attīstības pedagoǵiski psihologiskie nosacījumi pirmskolā: Pirmsskolas pedagogijas teorija praksei. Rīga: Librum.

5. Students, J. A. (1998). Vispārī̄gā Paidagogija I: Zinātne un māksla sevis un citu audzināšanā. R.: Raka, 329 lpp.

6. Vikmane, B. (1995). Latviešu tautasdziesma kā pirmsskolas vecuma bèrnu muzikālās dzirdes un balss attīstī̌sanas līdzeklis: Mūzikas pedagogija. Rīga: 48 lpp.

7. Vilde, I. (2013). Musicality development in music studies among primary school pupils. Summary of doctoral thesis. Rīga: LU, pp. 31 - 62

8. Žeigurs, A. (1993). Kā veicināt bèrna prāta spējas. Rīga: Igo \& Co, 24 lpp.

9. Айзенк, Г. Ю. (1992). Проверьте свои способности. Пер. с англ. М.: ПедагогикаПресс, 175 c.

10. Бодалев, А. А. (1988). Психология о личности. М.: ИМУ, 188 с.

11. Венгер, Л. А. (1973). Педагогика способностей. М.: Знание, 95 с.

12. Выготский, Л. С. (1997). Вопросы детской психологии. СПб.: Союз, 224 с.

13. Дружинин, В. Н. (2000). Психология общих способностей. СПб.: Питер, 368 с.: ил.

14. Запорожец, А. В. (1986). Избранные психологические труды: T.I. Психическое развитие ребенка. М.: Педагогика, 320 с.

15. Крайг, Г. (2002). Психология развития. СПб.: Питер. 992 с.

16. Мясищев, В., Готсдинер, А. (1992). Что есть музыкальность? //Музыкальная психология: Раздел 4. М.: с. 14.-29.

17. Петрушин, В. И. (1997). Музыкальная психология. 2-е изд. испр. и доп. М.: ГИЦ ВЛАДОС, $384 \mathrm{c.}$ 
Proceeding of the International Scientifical Conference May $23^{\text {th }}-24^{\text {th }}, 2014$ Volume I

18. Рубинштейн, С. Л. (1989). Основы общей психологии: В 2 Т. Т. ІІ. М.: Педагогика, $328 \mathrm{c.}$

19. Старчеус, М. С. (1996). Музыкальная одаренность: Гл.14 //Психология одаренности детей и подростков / под. ред. Н. С. Лейтеса. М.: Academia, с. 279. 318.

20. Теплов, Б. М. (1985). Избраныле труды: В 2-х T.T.I. М.: Педагогика, 328 с.

Dr. paed. Anna Liduma Riga Teacher Training and Educational Management Academy

e-mail: anna.liduma@rpiva.lv 